\title{
Effect of species composition, stand density and site index on the basal area increment of oak trees (Quercus sp.) in mixed stands with beech (Fagus sylvatica L.) in northern France
}

\author{
Sebastian HEIN ${ }^{\mathrm{a} *}$, Jean-François DHÔTE ${ }^{\mathrm{b}}$ \\ ${ }^{\text {a }}$ Forest Research Institute of Baden-Württemberg, Freiburg, Germany \\ ${ }^{\mathrm{b}}$ Laboratory of Forest and Wood Resources (LERFoB), UMR ENGREF/ INRA 1092, Nancy, France
}

(Received 16 August 2005; accepted 14 December 2005)

\begin{abstract}
We investigated the relationship between tree size and radial growth of oak in mixed oak-beech stands where beech basal area ranged from 0.0 to $98.2 \%$. We analysed 30 long-term permanent oak-beech plots in northern France with a total of 167 growth periods between 1904 and 2000 . The study was based on a nonlinear segmented model of individual tree basal area increment as a function of diameter at breast height, which is implemented in the French forest growth simulator Fagacées. We investigated variations of slope $\gamma$ from the linear branch of the segmented model for oak. We found stand density, species composition, and site index to have a significant influence. The basal area increment of oak decreased with rising admixture of beech and increased with site quality and lower stand density. The effect of beech admixture found in the present study corresponds with findings from tree physiology on below- and aboveground competition. Our results underline differences in competitiveness and long-term species dynamics in mixed oak-beech stands.
\end{abstract}

mixed-species stands / basal area growth / Quercus sp. / Fagus sylvatica / mixed model

Résumé - Effet du mélange, de la densité et de l'indice de fertilité sur l'accroissement en surface terrière du chêne (Quercus sp.) dans des peuplements mélangés avec du hêtre (Fagus sylvatica $\mathbf{L}$.) dans le nord de la France. Nous avons analysé la relation entre le diamètre du tronc et l'accroissement radial du chêne dans des peuplements mélangés de hêtre et chêne, où le pourcentage de hêtre varie entre 0,0 et $98,2 \%$. L'analyse s'appuie sur un réseau de 30 placettes permanentes situées dans le nord de la France avec au total 167 périodes d'accroissements entre 1904 et 2000. L'étude est basée sur un modèle non-linéaire segmenté pour l'accroissement en surface terrière en fonction du $\mathrm{D}_{130}$ de chaque arbre, comme il a été intégré dans le simulateur de croissance français Fagacées. Notre analyse est focalisée sur la variation de la pente gde la branche linéaire du modèle segmenté pour le chêne. La densité du peuplement, le pourcentage du hêtre dans le mélange et l'indice de fertilité ont un effet significatif sur la pente. L'accroissement en surface terrière de l'arbre diminue si le pourcentage du hêtre augmente. Il augmente avec l'indice de fertilité ainsi qu'avec la diminution de la densité du peuplement. L'effet mélange trouvé correspond bien aux résultats de la physiologie des arbres sur la compétition souterraine et aérienne. Nos résultats soulignent la différence de compétitivité entre les essences et la dynamique des essences dans des peuplements mélangés hêtre-chêne.

peuplements mélangés / accroissement en surface terrière / Quercus sp. / Fagus sylvatica / modèle effets mixtes

\section{INTRODUCTION AND OBJECTIVE}

Many recent silvicultural management programs have generally emphasised mixed stands (e.g., $[6,19])$. Mixed stands allow more flexibility for varying products of the wood market and changing public needs. Mixed stands are also believed to have higher stability against natural disturbances than pure stands [42,56-58].

Mixtures of oak (Quercus sp.) and beech (Fagus sylvatica L.) are spread widely throughout Western and Middle Europe [2]. These mixtures play an especially important role in forest management in France, whose national forests have a high proportion of sessile and pedunculate oak $(27.7 \%)$ and beech $(11.5 \%)$ [26]. For several reasons, oak and beech are often mixed. One specific reason is the maintenance of beech as

\footnotetext{
* Corresponding author: sebastian.hein@forst.bwl.de
}

an understorey species in oak stands to ensure sufficient shading of the trunk against epicormics (e.g., [7,25,55]). On sites originally dominated by beech, oak has often been cultivated for a long time but admixed beech remains present [24].

Only few results and modeling approaches on growth and yield, specifically for oak-beech mixtures, are available. What has been investigated extensively is the growth, productivity, and effects of silvicultural treatments in pure beech and oak stands. For example, Oswald [39], Kenk [29], Spiecker [55] and Bryndum [5] focused on site productivity, the effects of thinning, and crop tree management. Continually, among the few studies on mixed oak-beech stands, Freist-Dorr [20] found that volume production per hectare in mixed stands of oak and beech was lower than that in pure beech stands. In an earlier study, Bonnemann [4] found that intensive thinning of beech to favour oak in mixed oak-beech stands led to losses in volume 
increment per hectare. Preushler and Stögbauer [45] showed that tree height of oak in even-aged mixed stands was higher than that of beech only at early stages of development (between 30 and 60 years depending on site quality). Therefore, it can be concluded that the competitiveness of oak is low compared with beech $[43,44]$. However, modeling approaches of mixed oak-beech stands are scarce, even though the studies cited above give some insight into the growth and yield of these mixtures.

The objective of the present study was therefore to investigate the effect of beech admixture on the relationship between basal area increment and stem diameter of oak trees in oakbeech mixed stands. In order to study this effect, we used the core equation for oak from the growth simulator Fagacées. In addition we analysed its behaviour under differing situations of stand density, stand age, or site index.

\section{MATERIALS}

\subsection{Experimental Data}

We selected long-term permanent plots with oak-beech mixtures located in two geographical regions in Northern France. The two groups of plots "Bellême" and "Réno-Valdieu", with 16 and 10 plots respectively, were in Normandy/northwestern France, and the third group, "Haye", was in the Lorraine region in northeastern France (4 plots). A total of 33502 observations on 8005 trees were available. General information on the experiments and abbreviations is shown in Tables I and II. A detailed description of stand growth and yield parameters is provided in Pardé [40], Oswald [39] and Dhôte [11].

On most plots, silvicultural treatments changed over time. At the beginning of the study period a simple verbal description was often used, for instance 'light' or 'heavy thinning'. In the 1970's, Oswald's silvicultural norms were applied, which described the number of trees per hectare depending on the final average stem diameter [39, 40]. From 1995 and 1997, 'Rdi' (stocking percentage, [49]) was used on most of the plots [10]. Crop tree selection thinning was not on any of the plots.

The proportion of beech basal area on the plots ranged from 0.0 to $98.2 \%$. However, the stand structures of the plots differed, i.e. beech was mixed in an understorey species or a dominant species in the upper crown layer. The total dataset included 112 measurement periods with beech present in the dominant layer, and 55 periods with beech only present in the understorey or as intermediate individual trees. Nevertheless, for this analysis we only used plots in which oak was also present in the upper crown layer. The maximum change in the basal area of beech was between 20 and $30 \%$ points during the study period.

\subsection{The growth simulator Fagacées}

The relationships investigated here refer to the Fagacées growth simulator, a distance independent, age-related, individual tree growth simulator for pure, even-aged stands of beech and oak [41]. It was developed on the basis of data from long-term permanent plots in northern France [15]. The concept of Fagacées was first developed by Dhôte in 1991 [9] for pure beech stands and then expanded to pure oak stands [12]. Our analysis is based on the core equations of the French growth simulator Fagacées, which is, so far, parameterised for both pure beech and pure oak stands.

For oak, Fagacées describes the stand basal area increment as a function of dominant height, height increment of the dominant trees, and stand density. To allocate the stand basal area increment to the individual tree basal area increment, Fagacées uses a nonlinear "segmented model". In the segmented model, the evolution of basal area increment at $1.3 \mathrm{~m}$ height $(\Delta \mathrm{g})$ for individual trees is described with respect to a definite threshold $(\sigma$ in $\mathrm{cm})$ for stem diameter: trees below this threshold are assumed to not have basal area increment, while trees with a diameter larger than $\sigma$ increase in basal area. $\Delta \mathrm{g}$ is modelled as a linear function of stem diameter $(\mathrm{DBH})$ with slope $(\gamma$ in $\mathrm{cm}^{2} \mathrm{a}^{-1}$ ) intersecting the $\mathrm{x}$-axis at $\sigma$ (Eq. (1), Fig. 1; for details see Dhôte [12]).

Previous studies $[13,15]$ found that $\gamma$ does not vary with stand density or age for pure oak stands but depends solely on site quality. To ensure consistency between total basal area increment at the stand level and $\Delta \mathrm{g}$ of all individual trees, the sum of the latter is limited to the value for the whole stand [13]. Starting from the larger diameter side of a given distribution at a given diameter, when the sum reaches the stand basal area increment, the threshold $\sigma$ is set. And since the slope $\gamma$ is also dependent on stand density for beech, $\sigma$ is calculated by an iterative process. Here, slope $\gamma$ can be interpreted as the maximum efficiency for expanding crown space (and thus stem diameter) at a given time. The values $\gamma$ and $\sigma$ can explain differing growth patterns of social classes in pure, one-layer stands [12]. For example, oak $\gamma$ remains constant but $\sigma$ changes with thinning, while for beech $\gamma$ increases after thinning with no change in $\sigma$. Thus thinning favours large beech trees more than large oak trees.

\section{METHODS}

The methods are structured to analyse influencing factors on slope $\gamma$ for oaks in the mixed stands as described above. This is done in two steps as follows:

The segmented model of $\Delta \mathrm{g}$ as a function of DBH. First, we plotted the annual basal area increment of the trees over stem diameter per measurement period per plot. We had calculated annual increments by dividing the periodic increment by the period length. According to Dhôte $[9,12]$, we computed a nonlinear segmented regression (Eq. (1)) for each measurement period and plot [51].

$$
\begin{aligned}
\Delta \mathrm{g} & =0 ; & & \text { if } & & \mathrm{DBH} \leq \sigma \\
& =\alpha+\gamma \mathrm{DBH} ; & & \text { if } & & \mathrm{DBH}>\sigma
\end{aligned}
$$

where

$$
\sigma=-\alpha / \gamma
$$

To account for increasing variance with increasing stem diameter, observations were weighted by the inverse of the squared DBH (Eq. (2)).

$$
\text { weight }=1 / \mathrm{DBH}^{2} \text {. }
$$

Analysis of influencing factors on the slope $\gamma$.

Since we have different plots and different time periods, we related their slopes $\gamma$ to stand variables. Letting $\gamma_{i j}$ be the slope of $\Delta \mathrm{g}$ as a function of $\mathrm{DBH}$, we calculated each measurement period $i$, and plot $j$ from the segmented model. 


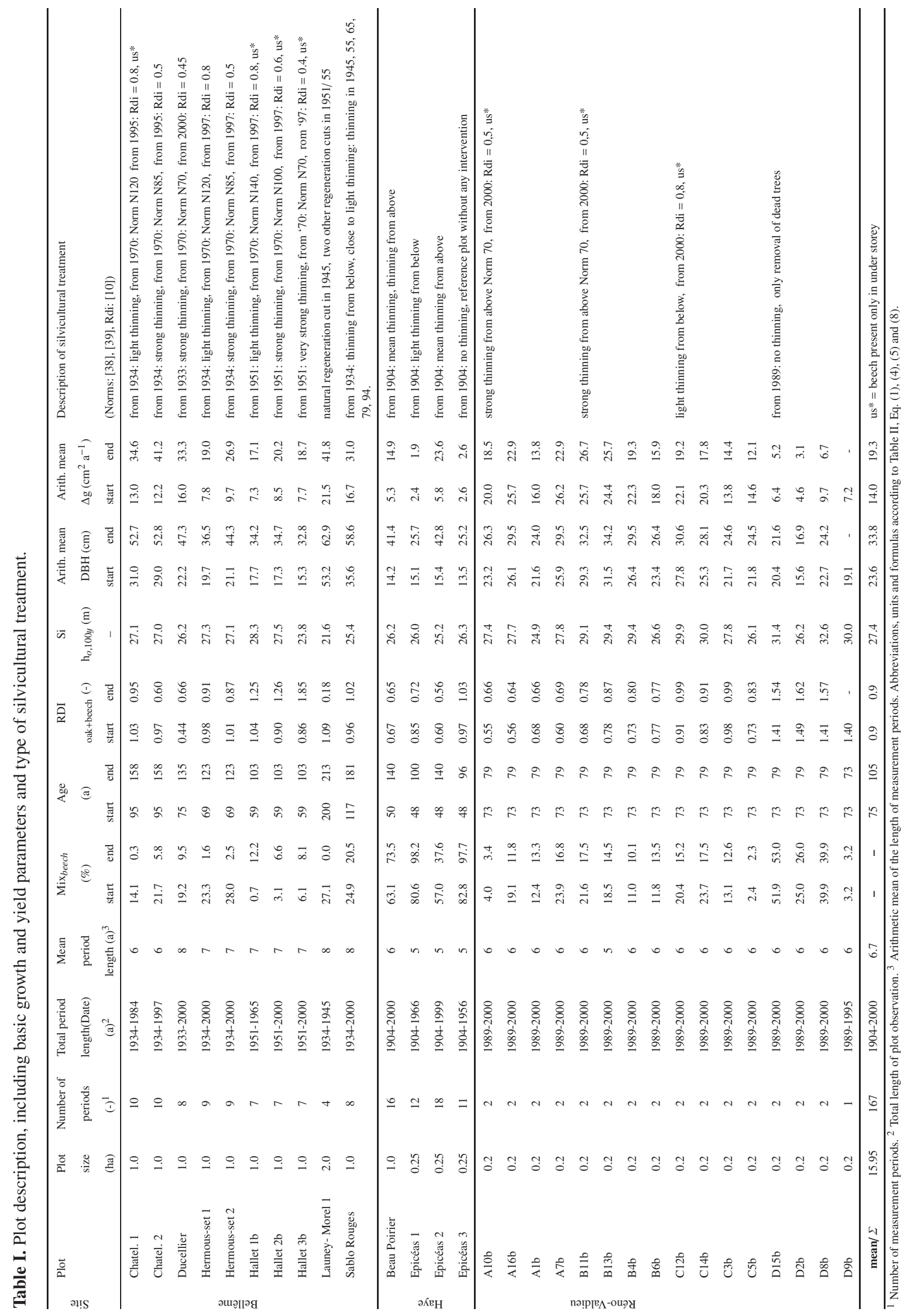


Table II. Explanation of symbols used.

\begin{tabular}{ll}
\hline Variable & Definition \\
\hline $\mathrm{Si}_{\text {oak }}$ & Site index expressed as dominant height at base age of $100 \mathrm{y}(\mathrm{m})$ \\
age $_{\text {oak }}$ & Stand age of oak at measurement (a) \\
$\mathrm{mix}_{\text {Beech }}$ & Admixture of beech as the basal area of beech/ total basal area of the stand $(\%)$ \\
$\mathrm{RDI}_{\text {oak }+ \text { beech }}$ & Relative density index $(-)$ \\
$\Delta \mathrm{g}$ & Periodic annual basal area increment at breast height $(1.30 \mathrm{~m})\left(\mathrm{cm}^{2} \times \mathrm{a}^{-1}\right)$ \\
$\Delta \mathrm{DBH}$ & Periodic annual diameter increment $\left(\mathrm{cm} \times \mathrm{a}^{-1}\right)$ \\
$\mathrm{DBH}$ & Diameter of the stem at breast height $(1.30 \mathrm{~m})(\mathrm{cm})$ \\
$\alpha, \gamma$ & Parameters of the nonlinear segmented model \\
$\alpha_{\mathrm{ij}}$ & Fixed effect parameters of the mixed model \\
$\mathrm{u}_{\mathrm{ij}}, \mathrm{e}_{\mathrm{ij}}$ & Variance components \\
$E$ & Mean error \\
$|E|$ & mean absolute error \\
$E^{2}$ & Mean squared error \\
$\mathrm{i}, \mathrm{j}$ & Subscripts for period, plot \\
\hline
\end{tabular}

We chose to consider stand density $\left(\mathrm{Rdi}_{\text {oak }+ \text { beech }}\right)$, admixture of beech $\left(\operatorname{mix}_{b e e c h}\right)$, stand (age age $\left.\mathrm{e}_{\text {oak }}\right)$, and site quality $\left(\mathrm{SI}_{\text {oak }}\right)$ as potentially influencing variables.

We calculated the stand density in two steps. We did this by using the self-thinning rule (Rdi, Eq. (3)) formulated by Reineke [49]. For parameters of the self-thinning rule, we used those suggested by Dhôte and Le Moguédec [15] for oak and beech in northern France (Eq. (3)). So, $\mathrm{C}_{\mathrm{g}}$ is the mean circumference of a tree at the beginning of the measurement period and $\mathrm{N}_{\max }$ is the maximum number of stems per hectare in a stand at a given $\mathrm{C}_{\mathrm{g}}$ (in $\mathrm{cm}$ ). For each species, we calculated the Rdi at the actual mean circumference by dividing the observed number of stems $\left(N_{\text {species }}\right)$ by the maximum number of stems $\left(N_{\text {max species }}\right)$ at that circumference (Eq. (4)). Then we calculated the Rdi value in mixed stands by adding the two species-specific Rdi (Eq. (5)):

$$
\operatorname{Ln}\left(\mathrm{N}_{\max }\right)=\mathrm{a}+\mathrm{b} \times \ln \left(\mathrm{C}_{\mathrm{g}}\right)
$$

$$
\begin{aligned}
\text { oak : } \quad a=14.000 \quad b=-1.701 \\
\text { beech : } \quad a=13.688 \quad b=-1.574 \\
\operatorname{Rdi}_{\text {species }}=\mathrm{N}_{\text {species }} / \mathrm{N}_{\text {max,species }} \\
\operatorname{Rdi}_{\text {oak+beech }}=\operatorname{Rdi}_{\text {oak }}+\mathrm{Rdi}_{\text {beech }} .
\end{aligned}
$$

Other possible effects were calculated as follows. Species composition was described as basal area of beech relative to total basal area of the mixed stand. Site quality was expressed as the dominant height at the base age of 100 years. For stands younger than the base age, we used height growth curves from Duplat and Tran-Ha Mien [16] (oak). Age was provided by the long-term permanent plot documents. Lastly, stand density and admixture of beech were calculated for each measurement period and plot.

The dataset has a hierarchical structure with measurement periods nested within plots. Thus, we applied the hierarchical linear models using the slope $\gamma$ from (Eq. (1)) as a dependent variable, and we calculated the following model (Eq. (6)):

$$
\begin{aligned}
\gamma_{\mathrm{ij}}= & \alpha_{0 \mathrm{j}}+\alpha_{1 \mathrm{j}} \operatorname{Rdi}_{\text {oak }+ \text { beech } \mathrm{ij}}+\alpha_{2 \mathrm{j}} \text { mix }_{\text {beech } \mathrm{ij}}+\alpha_{3 \mathrm{j}} \text { age }_{\text {oak }} \mathrm{ij} \\
& +e_{\mathrm{ij}} \text { period level }
\end{aligned}
$$

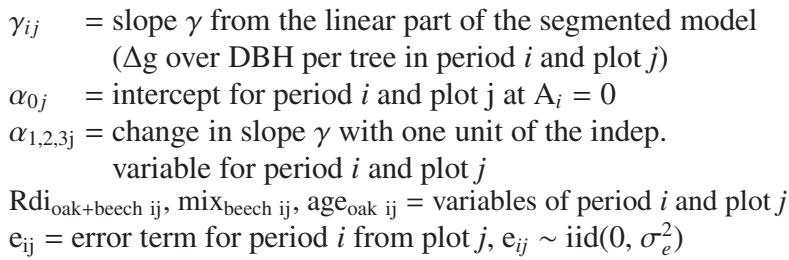

where subscripts $i$ and $j$ indicate measurement period and plot, respectively.

The regression coefficients $\alpha_{0 j}$ are then assumed to rise from a model at the plot level (Eq. (7)) where the variation of the intercept from the period level (Eq. (6)) is described by the plot level variable site index $\left(\mathrm{SI}_{o a k}\right)$. As the data were not from an experimental design with complete combinations of all factors, we tested a main-effect-only model for the fixed effects. A residual error term $u$ with $u_{0 j} \sim \operatorname{iid}\left(0, \sigma_{u 0 j}^{2}\right)$ was added to this model:

$$
\alpha_{0 \mathrm{j}}=\alpha_{00}+\alpha_{01} \mathrm{SI}_{\mathrm{oak} \mathrm{j}}+\mathrm{u}_{0 \mathrm{j}} \quad \text { plot level. }
$$

By substituting the coefficients of (Eq. (6)) by their level 2 definition from (Eq. (7)) we obtained a full hierarchical model in a single equation:

$$
\begin{aligned}
\gamma_{\mathrm{ij}}= & \alpha_{00}+\alpha_{1 \mathrm{j}} \operatorname{Rdi}_{\text {oak+beech }}+\alpha_{2 \mathrm{j}} \text { mix }_{\text {beech } \mathrm{ij}}+\alpha_{3 \mathrm{j}} \text { age }_{\mathrm{oak}} \mathrm{ij} \\
& +\alpha_{01} \mathrm{SI}_{\mathrm{oak} \mathrm{j}}+\mathrm{u}_{0 \mathrm{j}}+\mathrm{e}_{\mathrm{ij}} \quad \text { full cond. hierarchical model. }
\end{aligned}
$$


The effects of stand density ( $\operatorname{Rdi}_{\mathrm{o}} \mathrm{ak}+$ beech), species composition ( mix $_{\mathrm{b}} \mathrm{eech}$ ), stand age of oak (age $\mathrm{o}_{\mathrm{o}} \mathrm{ak}$ ), and site index of oak ( $\left.\mathrm{SI}_{\mathrm{o}} \mathrm{ak}\right)$ were then tested on the dependent variable $\gamma$.

The dataset contains multiple measurements at different time points of the response variable for subsequent measurement periods. As this may lead to errors which are not independent, we took the repeated measures structure of the data into consideration by choosing an appropriate covariance structure [34]. The parameters of the fixed effects $\alpha$ were estimated by the "generalised least squares" (GLS) method. The random effects $\mathrm{u}_{0} \mathrm{j}$ and $\mathrm{e}_{\mathrm{i}} \mathrm{j}$, as well as their variance and covariance matrix, were estimated by the "restricted maximum likelihood" (REML) method.

In order to validate our model [60,64], we split the dataset in two parts: for model evaluation, the data from plots Hallet 2b, Epicéas 1, and plots a1, a7, a10, and a16 in RénoValdieu were excluded from calibration (27 of 167 periods) because they cover different stand and site properties with low or high admixture of beech, light or heavy thinning regime, and measurement periods of different length. We will use the term "evaluation data set" when referring to these data, the term "modelbuilding data set" when referring to the calibration data. In order to examine the performance of the model, we used the fixed part of the model. The following error statistics were calculated:

$$
\begin{aligned}
E & =\sum\left(y_{i j}-\hat{y}_{i j}\right) / n \quad \text { mean error } \\
|E| & =\sum\left|y_{i j}-\hat{y}_{i j}\right| / n \quad \text { mean absolute error } \\
E^{2} & =\sum\left(y_{i j}-\hat{y}_{i j}\right)^{2} / n \quad \text { mean squared error }
\end{aligned}
$$

with $y_{i j}$ as the measured observation, $\hat{y}_{i j}$ as the predicted value, and $n$ as the number of observations.

The model evaluation was done using graphical (e.g., profile graphs $[23,59])$ and statistical criteria [34]. The standard errors of the parameters were used, including $t$-tests for inferences concerning the fixed- and random-effect parameters. The deviance statistic, calculated as the 2 likelihood ratio difference between the basic and the complex model, was taken to decide on model improvement. The level of significance was set to $\alpha=0.05$. We performed simulations to analyze the behaviour of the model [60]. All graphic and statistical analysis was realised with SAS [51].

\section{RESULTS}

The segmented nonlinear model (Eq. (1)) fit well in all of the 167 measurement periods. No systematic bias was found in the residuals. Figure 1 shows an example of the residual plots for two typical periods (C) with and (D) without oak understorey or intermediate trees.

The slopes $\gamma_{i j}$ of the 167 segmented models (Eq. (1)) were used as the dependent values in Eq. (8)). The parameter estimates of the conditional hierarchical model (Eq. (8)) are shown in Table III. The slope $\gamma_{i j}$ decreased with increasing stand density and increasing admixture of beech. The slope increased with increasing site index. Stand age had no significant effect on slope $\gamma_{i j}$. Even though a considerable amount of variation in slope $\gamma_{i j}$ could be explained, the inter-plot and inter-period variation components were still high. Multiple repeated measurements had no significant effect, even when we used unstructured variances or covariances for unequally spaced measurements [51] to take into account the repeated measurement structure of periods nested within a plot. Thus, in the end we decided not to include such a term in the model.

The average bias of the model was low $(-0.02$, Tab. III). As well, the error statistics of the model-building dataset were close to those from the evaluation data set. However, the mean absolute values were high, which indicates that there was still a large portion of unexplained residual variation in the data. The plot of the residuals revealed that the model was nearly unbiased for the model-building data set (Fig. 2). The mean error from the model-building dataset grouped by two plot categories was close to 0.0 both with beech as a main understorey species $(N=100)$ and with beech in the dominant layer $(N=40)$. Neither of these values (beech as understorey: -0.01 , beech in the dominant layer: 0.02 ) differed significantly from 0 .

However, when examining the residuals in different measurement periods, we found a period-specific bias (Figs. 2D and 3), such that slope $\gamma$ was underestimated for measurement periods in the 90s (Fig. 2D). In contrast, slopes $\gamma$ from the majority of the periods were overestimated in measurement periods from 1955 to 1980 (Fig. 2D). Thus, the bias in predicting basal area increments was also influenced by some measurement period-related effects not yet included in the model.

The behaviour of the model is demonstrated in Figure 4 for trees with DBH ranging from 15 to $40 \mathrm{~cm}$. Contrasting levels of the influencing factors (Rdi, admixture of beech, and site index of oak) were taken from the data range of the modelbuilding dataset. The model shows a response as expected from Dhôte [13] or Dhôte and Le Moguédec [15].

\section{DISCUSSION}

\subsection{Model building}

The present study extends earlier results of Deleuze et al. [8] and Dhôte [9, 13] on pure beech, oak, and Douglas fir stands to mixed-species stands of oak and beech. The aim of the study was to adapt one of the basic equations of the French growth simulator Fagacées for oak stands to mixed stands with oak and beech. The model developed in this study was based on tree measurements from long-term permanent plots. We used equations and variables that were previously found significant in other models developed using Fagacées. The use of multilevel linear models allowed for the hierarchical data structure with non-independent residuals to be taken into account.

The primary concept of the analysis was the segmented nonlinear model of annual periodic $\Delta \mathrm{g}$ as a function of $\mathrm{DBH}$. For even-aged stands, the annual periodic individual tree diameter increment at $1.3 \mathrm{~m}$ height $(\triangle \mathrm{DBH})$ as a function of $\mathrm{DBH}$ 
plot: d9b, period: $1989-1995$
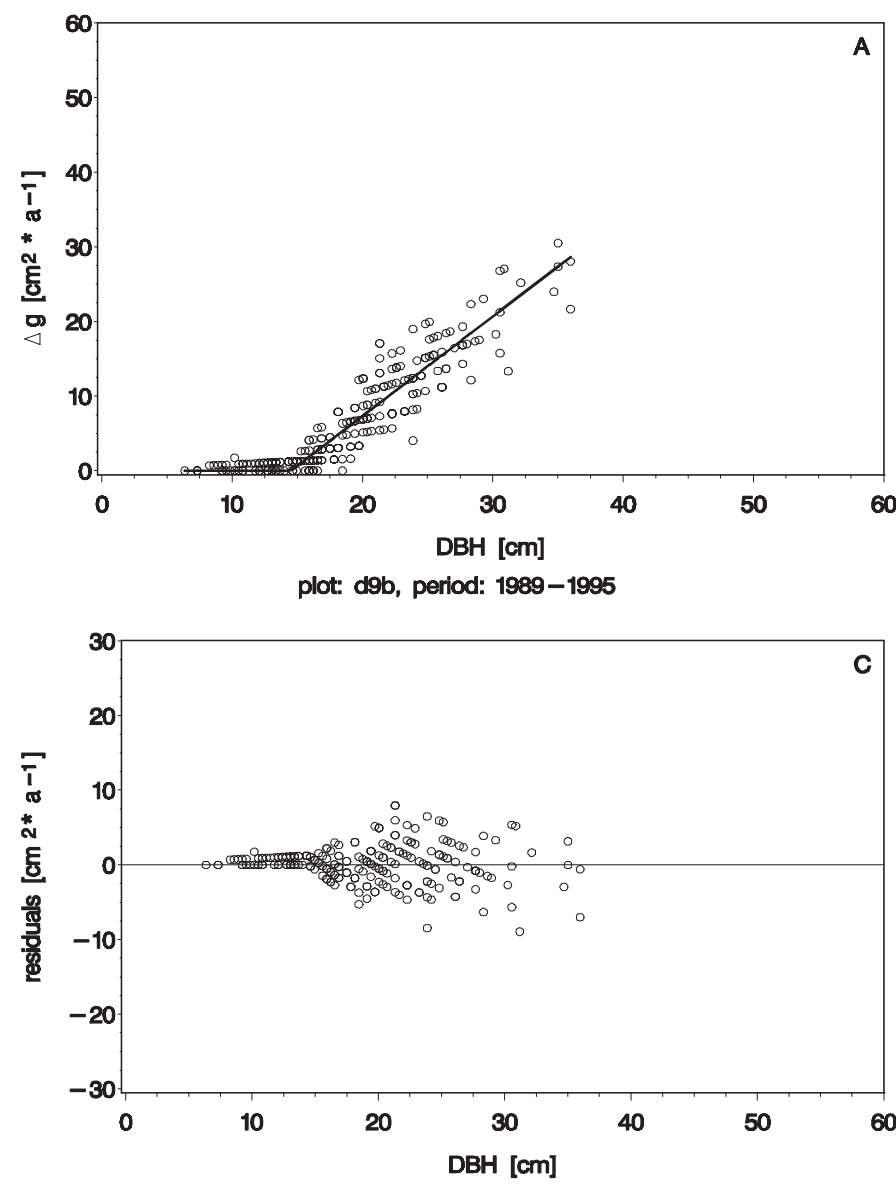

plot: b4b, period: $1995-2000$

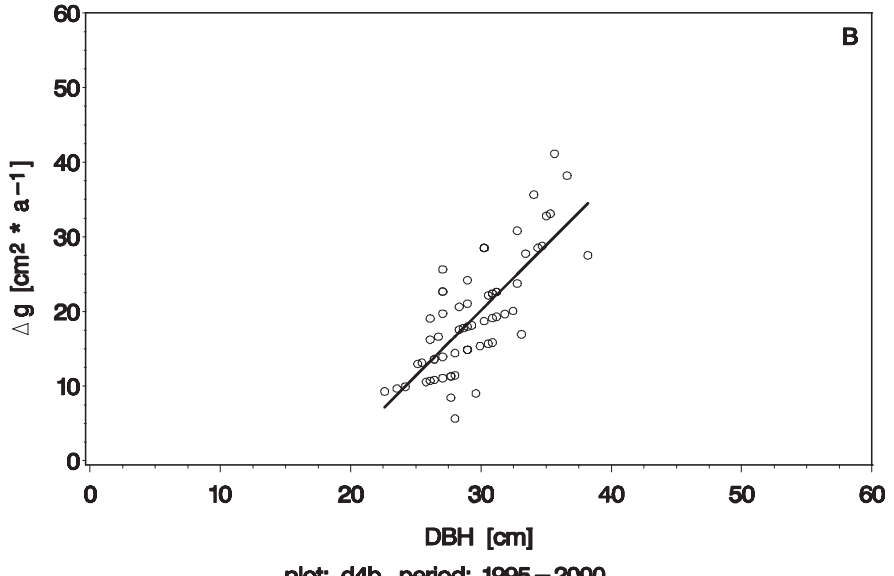

plot: d4b, period: $1995-2000$

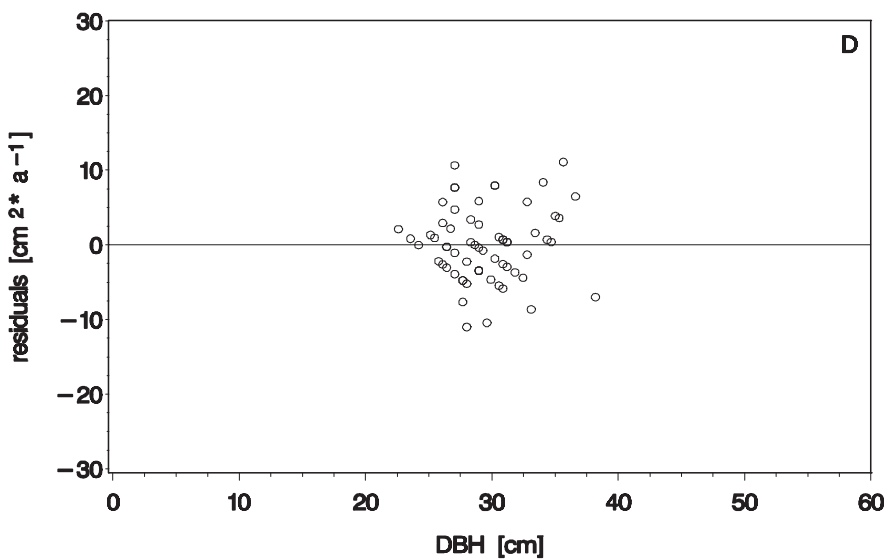

Figure 1. $\Delta$ g over DBH for oak; two selected periods: (A) plot d9b, period 1989-1995 with and (B) plot b4b, period 1995-2000 without oak-under storey or intermediate trees due to contrasting thinning regimes. Raw residuals from the non-linear segmented model: (C) plot d9b, period 1989-1995 and (D) plot b4b, period 1995-2000. DBH was measured as circumference in $1 \mathrm{~cm}$ classes, dot: observations, line: predicted values.

Table III. Estimates of the full conditional hierarchical model (Eq. (8)).

\begin{tabular}{|c|c|c|c|c|}
\hline Effects & Coeff. estimate & $\operatorname{se}\left(s_{x}^{-}\right)$ & $\begin{array}{l}Z \text {-value / } \\
t \text {-value }\end{array}$ & $\begin{array}{l}p>Z / \\
p>t\end{array}$ \\
\hline \multicolumn{5}{|l|}{ Fixed effects } \\
\hline Intercept & -1.3921 & 0.4819 & -2.89 & 0.0085 \\
\hline $\operatorname{Rdi}_{\text {oak }+ \text { beech }}$ & -0.3187 & 0.1139 & -2.80 & 0.0060 \\
\hline mix $_{\text {beech }}$ & -0.0047 & 0.0015 & -3.25 & 0.0015 \\
\hline $\mathrm{SI}_{\text {oak }}$ & 0.1092 & 0.0183 & 5.98 & $<0.0001$ \\
\hline \multicolumn{5}{|l|}{ Random effects } \\
\hline Residual error, (period level): error term $\mathrm{u}_{\mathrm{ij}}$ & 0.0682 & 0.0089 & 7.66 & $<0.0001$ \\
\hline $\begin{array}{l}\text { Plot level variance, (intercept): error term } \mathrm{e}_{0 j} \\
-2 \mathrm{LL}: 63.1\end{array}$ & 0.0200 & 0.0113 & 1.77 & 0.0385 \\
\hline Error statistics, model-building data set & \multicolumn{4}{|c|}{ Error statistics, evaluation data set } \\
\hline-0.0248 & $E$ & & & -0.0205 \\
\hline 0.2268 & $|E|$ & & & 0.3664 \\
\hline 0.0818 & $E^{2}$ & & & 0.1790 \\
\hline
\end{tabular}



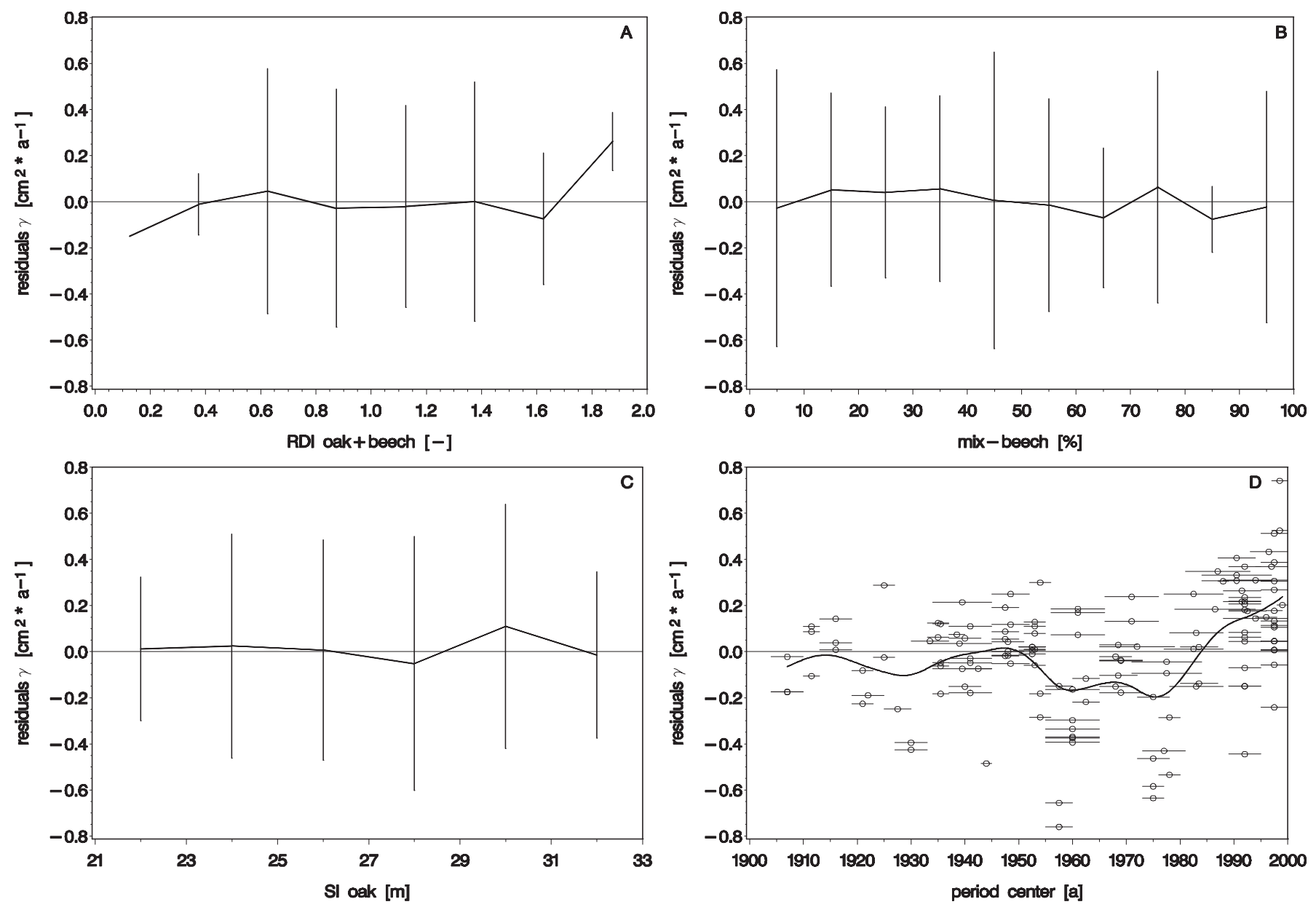

Figure 2. Raw residuals over stand density $\mathrm{RDI}_{\text {oak+beech }}(\mathrm{A})$, admixture of beech mix $_{\text {beech }}(\mathrm{B})$, site index $\mathrm{SI}_{100 \mathrm{y} \text { oak }}(\mathrm{C})$ and the center of the measurement period (D) for the model-building dataset (needles = standard deviation in each X-axis class, arithmetic mean joined, curve: cubic spline, smoothing $=50$, horizontal lines in lower right graph correspond to the length of the measurement period).

plot: a16b, period: 1989-1995

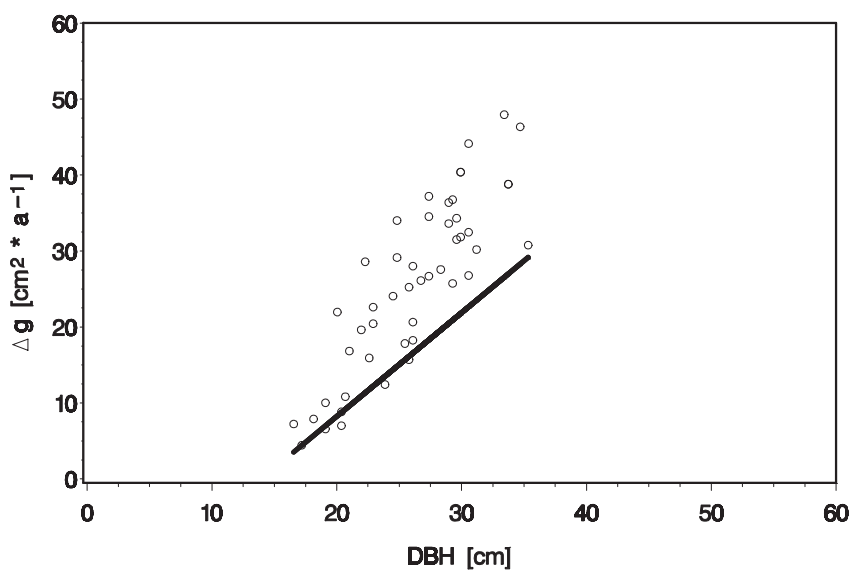

Figure 3. Observed (dots) and predicted (line) $\Delta \mathrm{g}$ as a function of DBH from the evaluation dataset, measurement period 1989-1995 of plot a16b, showing a bias in slope $\gamma$. has been shown as a simple linear function [46]. Subsequent analyses of Dhôte $[9,13]$ found a linear relationship between basal area increment over DBH for trees with a diameter larger than threshold $\sigma$. As basal area $(\mathrm{g})$ increment of individual trees is a function of $\mathrm{DBH}(\mathrm{g}=(\mathrm{DBH} \times \mathrm{DBH}) / 4 \times \pi)$, the graph of $\Delta \mathrm{g}$ over $\mathrm{DBH}$ should increase convexly by a quadratic term of DBH. However, recent analysis on Norway spruce showed that this relationship of $\Delta \mathrm{g}$ over $\mathrm{DBH}$ is linked to short term temporal variations in resource availability, such as climatic effects $[53,61]$. Thus, this relationship may be described by different curves for different years. In northern France, the relationship between $\triangle \mathrm{DBH}$ and $\mathrm{DBH}$ was found to be concave approaching a threshold of $\triangle \mathrm{DBH}$ in pure beech and oak stands [12]. In a recent study on Norway spruce and Douglas fir stands, Deleuze et al. [8] changed the simple linear relationship to an asymptotic relationship as $\Delta \mathrm{g}$ approached threshold $\sigma$. However, because of the analogy to the previous growth and yield models used in Fagacées, we used a segmented model with a linear relationship between $\Delta \mathrm{g}$ and DBH. Nevertheless, further research is needed on the relationship between stem size and its increment in pure and mixed stands. 
RDloak+ beech $($ solid $)=0.7, \quad$ RDloak + beech $($ dotted $)=1.5$

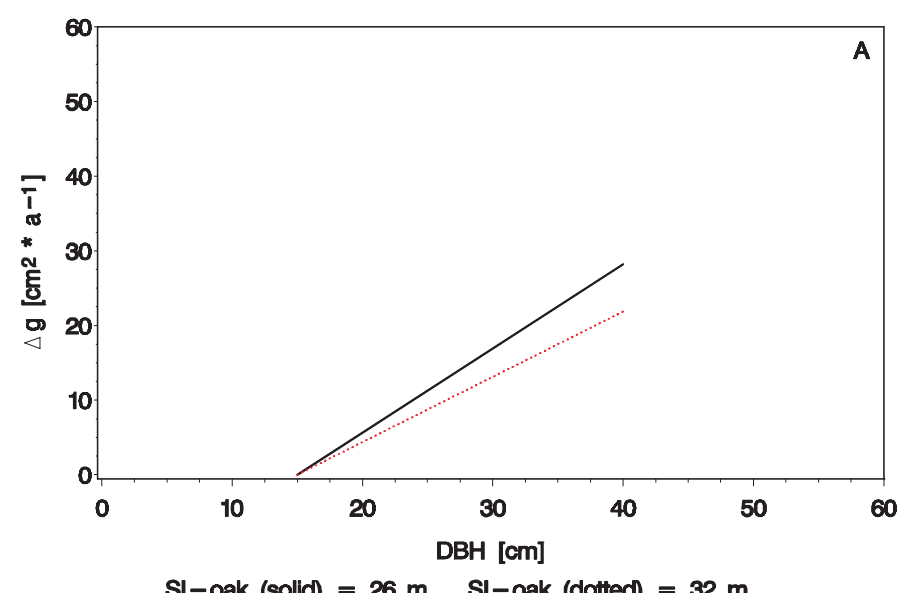

SI-oak (solid) $=26 \mathrm{~m}, \quad$ SI-oak (dotted) $=32 \mathrm{~m}$

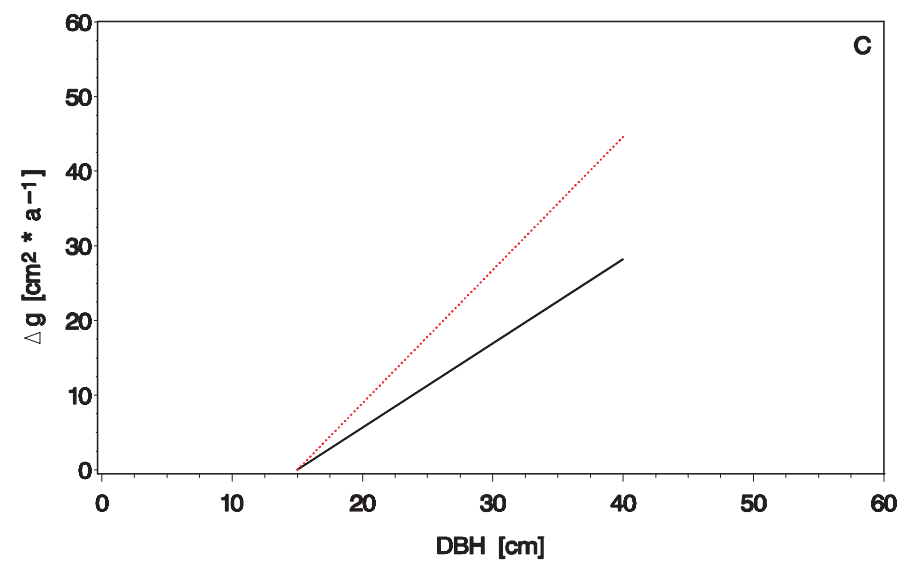

mix-beech $($ solid $)=20 \%, \quad$ mix-beech $($ dotted $)=80 \%$

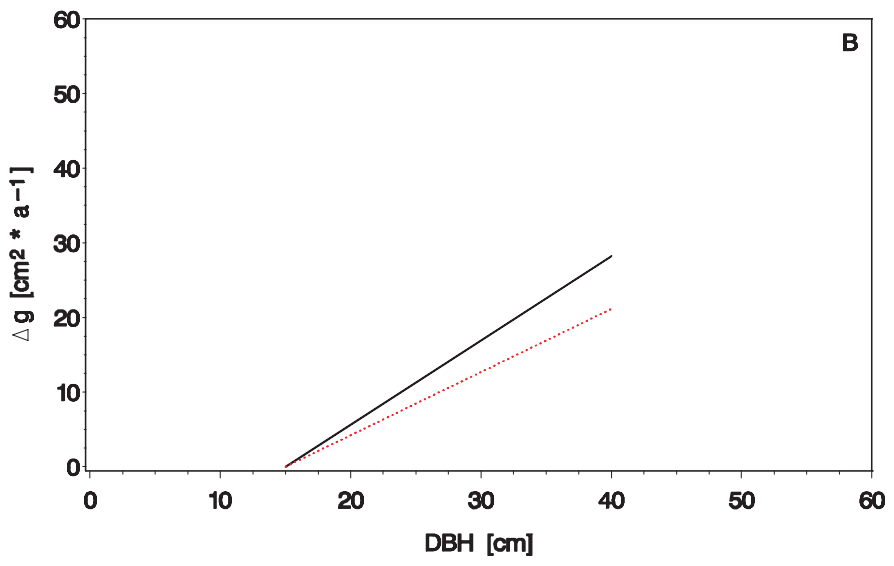

Figure 4. Simulated $\Delta \mathrm{g}$ of oak as a function of DBH for paired contrasting scenarios of stand density $\mathrm{RDI}_{\text {oak+beech }}(\mathrm{A})$, admixture of beech $\operatorname{mix}_{\text {beech }}(\mathrm{B})$ and site index of oak $\mathrm{SI}_{100 \mathrm{y} \text { oak }}(\mathrm{C})$ over a range of stem diameters at breast height between 15 and $40 \mathrm{~cm}$.

However, other distance-independent, individual tree models are built on different assumptions of stem diameter increment. Wykoff et al. [63] and Wykoff [62] predicted the periodic basal area increment as a function of transformed DBH in a longitudinal setting over the entire lifespan of an individual tree. This gives a positively skewed, unimodal diameter increment curve typical for tree growth processes Wykoff [62]. A similar method presented by Söderberg [54] now used in the HUGIN simulator also predicts individual tree basal area increment in longitudinal approach. Furthermore, González et al. [21] used difference equations for modeling longitudinal diameter increment series. In contrast to these approaches, the equation we used models the basal area growth in a crosssectional setting for all trees per measurement period. The Fagacées model structure ensures that the stem diameter increment lowers as trees age by distributing a smaller stand basal area increment to the individual trees [9].

In addition, our dataset is not based on crop-tree selection thinnings, but on stand-related thinning regimes. This partly explains the linear relation of $\Delta g$ and $\mathrm{DBH}$ per treatment. The DBH-range of the stands available has to be regarded as well. The integration of more stands with thicker trees at advanced stand ages could also modify the relationship in question to more curvilinear forms.

The stand density rule used in this study is a simplified approach based on Reineke's self-thinning rule [49], and made appropriate for integration into Fagacées. To make Reineke's rule appropriate, we used the parameters of the stand density rule calculated by Dhôte and Le Moguédec [15], and then applied them to the dataset available of oak and beech for northern France. Due to differences in the underlying datasets and methods, the parameters of Dhôte'S stand density rule differ slightly from the one described by Le Goff and Ottorini [30] or Pretzsch $[43,44]$, especially with regard to the parameter estimate of the slope, which has a specific meaning for competitiveness in pure or mixed stands. As no equations for specifically mixed oak-beech stands in northern France have yet been published, we used the parameterization of Dhôte and Le Moguédec [15], which serves as the base for Fagacées. In another approach used by Puettmann et al. [47], a maximum density surface is calculated for two species mixtures. However, their approach could not be used here either because no data on unmanaged mixtures of oak and beech were available. However, since the data for this study came from the same 
geographic region where Dhôte and Le Moguédec [15] set up their stand density rules, we were able to use their parameter estimates. Nevertheless, a further analysis should test the growth pattern found by Pretzsch $[43,44]$ for oak stands in northern France.

\subsection{Model results}

Site index was found to have a significant impact on slope $\gamma$ as the basal area increment was higher on more fertile sites than on less fertile sites. In their previous analysis on pure oak stands, Dhôte and Le Moguédec [15] also found that slope $\gamma$ was significantly related to site fertility but not to stand density. However in beech stands, they found that slope $\gamma$ is related to stand density. Therefore, they concluded that a thinning affects the basal area increment of oaks in a uniform way, independent of tree size. Small and large diameter oak trees have a similar response to thinnings, whereas for beech, larger diameter trees grow more than smaller diameter trees [12]. The hypothesis derived by Dhôte and Le Moguédec [15] was that beech reacts hierarchically to changes in stand density, and thus beech trees with larger diameters gain more from changes in density than those with small diameters. Therefore, the large beech trees expand their dominance in contrast to oak, where thinnings attenuate the hierarchical structure as all trees are favored without size considerations. Our results for oak from the present study contradict these assumptions. As stand density changes slope $\gamma$, thicker oak trees profited more from thinning in absolute terms than did thinner trees.

Continually, the presence of beech in mixtures affects the basal area increment of oak, such that beech admixture changes size hierarchy in oak stands by slowing the growth of thick oaks more than that of thin oaks [53]. A physiological explanation of this would be that thin oaks can activate previously unused resources before dying, for instance by budding epicormics [18]. Recent results on root development of oak and beech in mixed stands show that beech is a superior below- and aboveground competitor [33]. However, in years of high soil water deficit, oak is less affected than beech (e.g. [3, 48, 52]). Additionally, light transmittance of beech stands is lower than that of oak stands $[1,17]$, and as a consequence, less light is available for oak in mixed stands than in pure oak stands. Thus, beech is more competitive than oak, above as well as belowground (i.e. under western European conditions the growth of oaks is negatively affected by increasing beech proportion in stand composition).

However, such effects of beech present in oak stands may depend on the geographic region. In northern France, observed dominance of beech on the permanent plots can be reversed. For example, in the "Tillaie" natural forest reserve in Fontainebleau/France, beech dominates oak as on many other sites in northern France, but in the drier site conditions of central France (e.g., Forêt de Blois) oak dominates beech [22]. In addition, the percentage of the basal area of beech may not represent the true impact of species interaction. Spatial analysis of oak and beech in mixed stands with different mingling patterns showed that oak had a higher chance of surviving in stands dominated by beech when clustered in groups [22]. Another factor which can lead to a dominance of beech, due to its superior growth, is the availability of light. When photosynthetically active radiation is low, height growth and survival of oaks is inferior to that of beech [36].

The results presented here agree with findings of Pretzsch $[43,44]$, who found that oak exhibits different behaviour in mixtures than in pure stands. In pure stands, the coefficient b for oak from (Eq. (3)) is lower than that of beech, whereas in mixtures the order is reversed. This indicates that beech is more competitive than oak. In mixed oak-beech stands, selfthinning of beech occurs later, indicating that beech has a higher growing space efficiency and thus crowds out oak [44].

Variations in weather can also have an impact on basal area increment [30]. Even though the evaluation dataset was based on a large variety of period-site-thinning combinations, the model failed in some measurement periods. The predictions of the model underestimated the $\Delta \mathrm{g}$ for periods during the 90 's. Furthermore, the model overestimated slope $\gamma$ in the majority of periods between 1955 and 1980. We assume that the rather high random variation at period level (Tab. III) and the residual pattern mentioned above may partly be due to the exceptional weather conditions or fluctuations in productivity specific for these time intervals [14].

Our results contradict some earlier findings by FreistDorr [20]. Modeling the growth of mixed oak-beech stands based on German long-term growth and yield experiments, it was found that tree species did not have a significant influence on basal area increment of individual trees. The basal area increment of oak had only a moderate tendency to be lower if beech trees were neighboring. Röhle [50] also found statistical relationships between $\Delta \mathrm{g}$ and $\mathrm{DBH}$ within a mixed stand dominated by oak. Even though qualitative aspects of possible differences in stand age and site fertility in slope $\gamma$ were discussed, the effects of species mixtures were not analysed. Furthermore, it was simply concluded that slope $\gamma$ was lower in older stands growing on sites with low fertility.

\section{CONCLUSIONS}

The model developed in this study, an adaptation of the French forest growth simulator Fagacées for mixed species stands, provides initial insight for assessing basal area increment of oaks in mixed stands with beech. Even though the predictions of the model were biased in some measurement periods, the overall behaviour of the model was logical within the limits of the dataset used. The model is able to quantify the effects of beech mixture on the basal area increment of oak.

Because our model describes the effects of species mixture at the tree level not the stand level, no conclusions can be made with regard to changes in per hectare productivity due to this variable [28]. Further research is needed to address this issue.

The results of our study confirm applied experience in silviculture. If silvicultural activities in favour of oak are reduced, natural tree species dynamics will usually lead to a new domination of beech and decreasing proportions of admixed oak $[27,31,32,35,37,38]$. As a silvicultural consequence, 
oak should be favored in thinnings of mixed oak-beech stands to prevent a decrease in its basal area increment. In order to ensure a high diameter increment of oak it would thus be necessary to reduce stand density. These findings on the competitiveness of oak versus beech agree with ecophysiological results on below and aboveground competition in mixed stands.

Acknowledgements: We would like to thank Michel Ravart and Daniel Ritié for the field work on French mixed oak-beech plots. We are also grateful to Robin Hillestad cand. M.Sc. for revising the language of the manuscript.

\section{REFERENCES}

[1] Aussenac G., Ducrey M., Bioclimatological study of a broadleaved stand (Fagus sylvatica L. et Quercus sessiliflora Salisb.) in the east of France, Ann. Sci. For. 54 (1991) 265-284 (in French with English summary).

[2] Bartelink H.H., Olsthoorn A.F.M., Mixed Forests in Western Europe, In: Olsthoorn A.A. et al., Dutch. Inst. For. Nature Res. (Eds.), Management of mixed-species forest: silviculture and economics, Wageningen, 1999, pp. 9-15.

[3] Bonn S., Tree species dynamic in mixed oak-beech forests and expected modifications due to climate change, Allg. Forst- Jagdztg. 171 (2000) 81-88 (in German with English summary).

[4] Bonnemann A., oak-beech mixed stands, Universität Göttingen, Forstwissenschaftliche Fakultät, Habilitationsschrift, Göttingen, 1955 (in German).

[5] Bryndum H., the thinning trial with beech in the totterup forest, Saertyk af det forslige Forsøgsvaesen i. Danmark 38, 1980 (in Danish with English summary).

[6] BW-LFV, Guideline for general forest development types, Ministry for Rural Space, Nutrition, Agriculture and Forestry of BadenWürttemberg, Forest Service of Baden-Württemberg, Stuttgart, 1999 (in German).

[7] Colin F., Analysis and modeling of branching pattern as linked to wood properties, transfer to the evaluation and improvement of wood resources, Nancy, Université Henri Poincaré Nancy I, Dossier de candidature - Habilitation à Diriger des Recherches, 2003 (in French with English summary).

[8] Deleuze C., Pain O., Dhôte J.-F., Hervé J.-C., A flexible radial increment model for individual trees in pure and even-aged stands, Ann. For. Sci. 61 (2004) 327-335.

[9] Dhôte J.-F., Modeling of growth of regular beech stands: dynamic of social hierarchy and factors influencing productivity, Ann. Sci. For. 48 (1991) 389-416 (in French with English summary).

[10] Dhôte J.-F., Definition of thinning scenarios for beech and oaks, Rev. For. Fr. (Nancy) XLVII (1995) 106-110 (in French with English summary).

[11] Dhôte J.-F., Effect of thinning on the development of dominant diameter in regular beech or oak stands, Rev. For. Fr. (Nancy) XLIX (1997) 557-578 (in French with English summary).

[12] Dhôte J.-F., Competition between social classes of sessile oak and beech, Rev. For. Fr. (Nancy) LI (1999) 309-325 (in French with English summary).

[13] Dhôte J.-F., Modeling the growth dynamic of stands with the social broadleaves, transfer to silviculture of beech and oaks, Nancy, Université Henri Poincaré Nancy I, Dossier de candidature Habilitation à Diriger des Recherches, 1999 (in French with English summary).

[14] Dhôte J.-F., Hervé J.-C., Changes in productivity in four sessile oak stands since 1930: an approach at stand level, Ann. For. Sci. 57 (2000) 651-680 (in French with English summary).
[15] Dhôte J.-F., Le Moguédec G., Reference of the Fagacées growth simulator, Nancy-Champenoux, 2004 (in French).

[16] Duplat P., Tran-Ha Mien, Modeling dominant height growth of sessile oak (Quercus petraea Liebl) in France - Inter-regional variability and effect of recent growth periods (1959-1993), Ann. For. Sci. 54 (1997) 611-634 (in French with English summary).

[17] Ellenberg H., Vegetation of Middle Europe with the Alps from an Ecological, Dynamic and Historical Perspective, Ulmer, Stuttgart, 1996 (in German).

[18] Fontaine F., Colin F., Jarret P., Druelle J.-J., Evolution of the epicormic potential on 17-year-old Quercus petraea trees: first results, Ann. For. Sci. 58 (2001) 583-592.

[19] FR-ONF, Regional Forest Guidelines for the Lorraine Region, Ministère de l'Agriculture et de la Pêche, Tomes 1 and 2, Paris, 1998 (in French).

[20] Freist-Dorr M., Structure and Growth of South Western Sessile Oak-Beech Mixed Stands: Presentation Exemplified by LongTerm-Permanent Plots, München, Forstliche Forschungsberichte München, Schriftenreihe der Forstwissenschaftlichen Fakultät der Universität München und der Bayer. Forst- u. Forschungsanstalt, Ph.D. dissertation, 1992 (in German).

[21] González M.S., Tomé M., Montero G., Modelling height and diameter growth of dominant cork oak trees in Spain, Scand. J. For. Res. 8 (2005) 633-643.

[22] Goreaud F., Contributions to the analysis of spatial structure in a temperate forest for the modeling of complex forests, Ph.D. dissertation, Nancy, 2000 (in French with English summary).

[23] Gregoire T.G., Schabenberger O., Barret J.B., Linear Modelling of Irregularly Spaced, Unbalanced, Longitudinal Data from Permanent-Plot Measurements, Can. J. For. Res. 25 (1995) 137156.

[24] Hasel K., Schwartz E., Forest History, Kessel, Remagen, 2002 (in German).

[25] Henriksen H., Sanojca K., Influence of an understorey of beech on the development of epicormic branches of Quercus robur, Forstlige Forsogsvaesen i Danmark 39 (1983) 94-119 (in Danish with English summary).

[26] IFN-FR, French National Forest Inventory, www.ifn.fr, 2005.

[27] Jahn G., Die Buche auf dem Vormarsch in Flachland des nordwestlichen Mitteleuropa, Forst- u Holzwirt. 38 (1983) 142-143.

[28] Kelty M.J., Comparative productivity of monocultures and mixedspecies stands, In: Kelty M.J., Larson B.C., Oliver C.H.D. (Eds.), The Ecology and Silviculture of Mixed-Species Forests, 1992, pp. $125-141$.

[29] Kenk G., Silvicultural Program "Valuable Oak", Reflections on a Forest Planning Type, [EM-8-80], Ministerium für Ernährung, Landwirtschaft Umwelt und Forsten, Stuttgart, 1979 (in German).

[30] Le Goff N., Ottorini J.M., Effect of thinning on the growth of beech, interactions with climatic factors, Rev. For. Fr. (Nancy) LI-2 (1999) 355-364.

[31] Leuschner C., Forest dynamics on sandy soils in the Lüneburger Heide, Phytooecologia 22 (1994) 289-324 (in German with English summary).

[32] Leuschner C., Mechanisms of competitive superiority of beech, Berichte der Reinhard-Tüxen-Gesellschaft 10 (1998) 5-18 (in German with English summary).

[33] Leuschner C., Hertel D., Coners H., Büttner V., Root competition between beech and oak: a hypothesis, Oecologia 126 (2001) 276284.

[34] Littell R.C., Milliken G.A., Stroup W.W., Wolfinger R.D., SAS System for Mixed Models, NC, USA, 1996.

[35] Lüpke V.B., Silvicultural methods of oak regeneration with special respect to shade tolerant mixed species, For. Ecol. Manage. 106 (1998) 19-26. 
[36] Lüpke V.B., Hauskeller-Bullerjahn K., A contribution to the modelling of young stands exemplified by sessile oak-beech mixed natural regenerations, Allg. Forst- Jagdzgt. 175 (2004) 61-69 (in German with English summary).

[37] Meyer P., Unkrig W., Griese F., Development of beech (Fagus sylvatica L.) in north-west german forest reserves, Forst Holz 55 (2000) 470-477 (in German with English summary).

[38] Otto H.-J., Driving forces of natural dynamics in European beech forests, Forst Holz 57 (2002) 649-653 (in German with English summary).

[39] Oswald H., Main results from experimental plots with oak from the National Center of Forest Research, Rev. For. Fr. (Nancy) XXXIII, No. spécial (1981) 65-85 (in French with English summary).

[40] Pardé J., Normes on silviculture for sessile oak stands, Rev. For. Fr. (Nancy) XXX (1978) 11-17 (in French with English summary).

[41] Pretzsch H., Conception and Construction of Growth Models for Pure and Mixed Forests, Universität München, Forstliche Forschungsberichte München, Schriftenreihe der Forstwissenschaftlichen Fakultät der Universität München und der Bayerischen Forstlichen Versuchs- und Forschungsanstalt, Habilitationsschrift, 1992 (in German with English summary).

[42] Pretzsch H., Pure and Mixed Stands under the Influence of Disturbing Factors: Elasticity and Resilience of Growth, Göttingen, 2004, 382-395, Deutscher Forstverein e.V., 61. Jahrestagung, Forstwirtschaft im Dialog - Gemeinsam die Zukunft gestalten!, 2528 September 2003 in Mainz (in German).

[43] Pretzsch H., A re-evaluation of Reineke's rule and stand density index, For. Sci. (2006) (in press).

[44] Pretzsch H., Yoda's 3/2 power law of self-thinning, a stimulating myth, Oecologia (2006) (in press).

[45] Preuhsler T., Stögbauer K., Structural traits of the veneer oak stand "Eichhall" in the Bavarian forest district of Rohrbrunn, Forst Holz 45 (1990) 283-289 (in German with English summary).

[46] Prodan M., Forest Measurement, J.D. Sauerländer's Verlag, Frankfurt a. M., 1965 (in German).

[47] Puettmann K.J., Hibbs D.E., Hann D.W., The dynamics of mixed stands of Alnus rubra and Pseudotsuga menziesii: extension of sizedensity analysis to species mixture, J. Ecol. 80 (1992) 449-458.

[48] Raftoyannis Y., Radoglou K., Physiological responses of beech and sessile oak in a natural mixed stand during dry summer, Ann. Bot. 89 (2002) 723-730.

[49] Reineke L.H., Perfecting a stand-density index for even-aged forests, J. Agric. Res. 46 (1933) 627-638.

[50] Röhle H., Structure and Growth of Pedunculate Oak Mixed Forests on Ground Water Influenced Site in the Floodplains of Southern Bavaria, Universität München, Forstliche Forschungsberichte
München, Schriftenreihe der Forstwissenschaftlichen Fakultät der Universität München und der Bayerischen Forstlichen Versuchsund Forschungsanstalt, Dissertation, 1982 (in German with English summary).

[51] SAS9.12004, SAS/STAT 9.1 User's Guide, SAS Publishing, Cary.

[52] Schraml C., Rennenberg H., Sensitivity of different ecotypes of beech trees (Fagus sylvatica L.) to drought stress, Forstwiss. Cent.bl. 119 (2000) 51-61 (in German with English summary).

[53] Schwinning S., Weiner J., Mechanisms determining the degree of size asymmetry in competition among plants, Oecologia 113 (1998) $447-455$.

[54] Söderberg U., Functions for Forecasting Timber Yield: Increment and Form Height of Individual Trees of Native Tree Species in Sweden, Rapport, Avdelnigen för Skogsuppskattning och Skogsindelning 14, Sveriges Lantbruksuniversitet, Umeå, 1986 (in Swedish with English summary).

[55] Spiecker H., On the Growth Control and Natural Pruning of Sessile and Pedunculate Oak (Quercus petrea (Matt.) Liebl. and Quercus robur L.), Schr. reihe Landesforstverwalt, Baden-Württ., Stuttgart, 1991 (original in German).

[56] Thomasius H., Stability, elasticity and resilience of forest ecosystems under the influence of acid depositions, Forstarchiv 58 (1987) 232-239 (in German with English summary).

[57] Thomasius H., Stability of natural and artificial forest ecosystems and their interference by forest measures, Allg. Forst-Jagdztg 39 (1988) 1064-1068 (in German with English summary).

[58] Thomasius H., Stability of natural and artificial forest ecosystems and their interference by forest measures, Allg. Forst-Jagdztg 38 (1988) 1037-1043 (in German with English summary).

[59] Tufte E.R., The Visual Display of Quantitative Information, Graphics Press, Cheshire, Connecticut, 2001.

[60] Vanclay J.K., Skovsgaard J.P., Evaluating forest growth models, Ecol. Model. 98 (1997) 1-12.

[61] Wichmann L., Modelling the Effects of Competition Between Individual Trees in Forest Stands, 112, Copenhagen, Denmark, The Royal Veterinary and Agricultural University, 2002.

[62] Wykoff W.R., A basal area increment model for individual conifers in the northern Rocky Mountains, For. Sci. 36 (1990) 1077-1104.

[63] Wykoff W.R., Crookston N.L., Stage A.R., User's Guide to the Stand Prognosis Model, USDA For. Serv. Gen. Tech. Rep, INT-133, Ogden, Utah, 1982.

[64] Yang Y., Monserud R.A., Huang S., An evaluation of diagnostic tests and their roles in validating forest biometric models, Can. J. For. Res. 34 (2004) 619-629. 